\title{
O CONCEITO DE JUSTIÇA ANTONIANO E A SUA DIMENSÃO ÉTICA
}

José Antônio de C. R. de Souza'

SÍNTESE - Santo Antônio de Lisboa (ou de Pádua), na qualidade de pregador, deixou um legado de sermões, nos quais encontra-se toda uma visão de vida cristã. $\mathrm{A}$ obra não pode ser qualificada como pertencente a um filósofo, tal como se deu este nome a outros seus contemporâneos, mas possui denso conteúdo teórico, como, por exemplo, no que se refere à dimensão ética do conceito de justiça.
ABSTRACT - Saint Antony of Lisbon (or of Padua) has lett as preacher a legacy of sermons in which we find a conspectus of Christian life. It isn't a philosophical work, like those of other authors, but it comprises a dense theoretical content concerning for instance to the ethical dimension of the concept of justice.

Fernando Martins de Bulhões, mais conhecido pelo nome religioso de Frei Antônio O.M., e venerado como Santo Antônio, de Pádua, onde morreu em 13 de junho de 1231, ou de Lisboa, onde nasceu à volta de 1190, ou do mundo todo, porque seu culto se consolidou como tal, dado que é tido na conta de poderoso taumaturgo, não é paradoxalmente conhecido em nosso País como intelectual e fundador da Escola Franciscana de Pensamento.

Com efeito, a rápida canonização de Santo Antônio, ocorrida menos de um ano após o seu transitus, em 30 de maio de 1230, promulgada por Gregório IX (1227-41), dados o seu testemunho de vida como pessoa virtuosa e coerente, e também pela fama de que tinha gozado como pregador e taumaturgo, e ainda, a sua inconteste popularidade em todo o mundo, em especial por onde se irradiou a cultura portuguesa, fizeram com que, durante muitos séculos, não se tivesse notado o intelectual de envergadura que um dia se escondera, e apenas durante onze anos (1220-1231), num rústico hábito franciscano. Noutras palavras, podemos dizer que a canonização de Antônio contribuiu para que ele fosse esquecido como intelectual.

Departamento de História e Curso de Mestrado em Filosofia Política - Universidade Federal de Goiás (UFG). Bolsista do CNPq. 
Ademais, também faz muito pouco tempo que começaram a vir a lume não apenas estudos com o rigor científico exigido, acerca de sua obra e do contexto sócio-cultural em que viveu, mas também as edições críticas de seus Sermões, inclusive em língua portuguesa. ${ }^{\circ}$

No entanto, o prestígio como pregador de que, logo, Frei Antônio passou a gozar, fez com que o Poverello de Assis, em 1222, lhe desse u'a missão especial: "A Frei António, meu bispo, Frei Francisco envia saudações. Apraz-me que ensines Teologia aos frades, contanto que por tal estudo não extingas o espirito da oração e devoção, como está contido na Regra. Adeus" "

Foi essa incumbência que provocou uma virada radical na história do franciscanismo primitivo. O Fundador, por assim dizer, estava a "dar o sinal verde" para o início da atividade intelectual no âmbito da Ordem, ${ }^{3}$ atividade essa não considerada como fim em si mesma, mas como um instrumento para que outras metas mais importantes, como a pregação da Boa Nova, e a conversão dos pecadores, pudessem vir a ser alcançadas. Francisco notou que era possivel, ao mesmo tempo, ser sábio e simples, humilde e culto como o era Frei Antônio.

Por conseguinte, sem o receio de estar a cometer exageros, afirmamos que 0 Santo foi o fundador da Escola Franciscana de pensamento, pelo fato de, obedecendo a Francisco, ter passado, desde então, a ensinar nas escolas conventuais de Bolonha, de Toulouse e de Montpellier entre os anos de 1222-27, e de Pádua, desde 1229 até sua morte em 1231, sem, no entanto, jamais ter deixado de continuar a pregar para o povo, com vista a convertê-lo, vocação essa para a qual se sentia realmente chamado.

Entretanto, cometeria erros palmares quem imaginasse que os Sermões antonianos se assemelham às homilias contemporâneas; que foram ditos aos fiéis em geral. Na verdade, não há sequer um sermão de Frei Antônio escrito em língua vulgar, por exemplo, ou em vêneto ou na "langue d'oc" (provençal), conquanto ele tivesse pregado para as massas citadinas nessas idiomas. Os Sermões foram escritos em Latim. Para além da sua estrutura intrínseca, vigente àquela época, tinham no seu bojo não apenas um tema único, haurido nos textos da Escritura lidos na missa do dia, mas também outros temas, ou melhor, tratava-se de um sermão principal do qual se desdobravam outros sermões menores, dado que tais textos se destinavam precipuamente a ensinar oratória sacra aos frades estudantes de Teologia, que mais tarde iriam ser pregadores.

É preciso, entretanto, esclarecer que Santo Antônio não foi um filósofo ou um teólogo, do mesmo modo como a Histónia considera outros autores famosos de sua

\footnotetext{
Neste estudo utilizaremos a edição bilingüe elaborada por Henrique Pinto Rema OFM, Santo António de Lisboa Obras Completas Sermōes Dominicais e Festivos, 2 vols. Porto, Lello \& Irmão Editores, 1987.

2. Chronica XXIV Generalium, ed. Annalecta Franciscana, III: 132.

3 Cfr. BALIC, C., "Sant'Antonio e la Sçolastica Francescana", S. Antonio Dottore della Chiesa, Atti delle due settimane antoniane teneute a Roma e a Padova nel 1946, Vaticano, Poliglota Vaticana, 1947: 15-30. LOMBARDI, T., "Sant'Antonio di Padova Maestro di Teologia a Bologna. II problema degli Studi Agli Inizi dell'Ordine Francescano", in Atti del Congresso Internazionale di Studio sui Sermones di S. Antonio di Padova, a cura de Antonino Poppi, Pádua, Ed. Messaggero, 1982: 797819. VENTOSA, E.R., "San Antonio, Representante de la Primeira Generación del Pensamiento Franciscano", Cuadernos Salamantinos de Filosofia, 22 (1995): 117-134.
} 
época, em vista dos textos que legaram para a posteridade. Aliás, sua produção intelectual, se constitui precisamente de.um amplo conjunto de sermões, subdividido em dois blocos, um dos quais designado por Sermões Dominicais e o outro, por Sermões Festivos. É nesse conjunto que se encontra assistematicamente espalhado o pensamento antoniano, manancial de idéias bastante rico que oferece inúmeras possibilidades de investigação.

Um tema/conceito que se destaca entre os muitos, tratados por Santo Antônio em seus Sermões, face à sua importância, é aquele relativo à Justiça.

Pretendemos com este estudo, de um lado, analisar este assunto/conceito, segundo a visão do Santo, e de outro, nela apoiado, ressaltar sua dimensão ética, aplicando-o à nossa realidade. Trataremos deste tema, na medida em que seja possivel, comparando o que ele escreveu nos Sermones Dominicales e nos Festivi."

Num trecho, por exemplo, do sermão alusivo ao $15^{\circ}$ Domingo depois de Pentecostes, o Frade Menorita diz que o homo christianus, a quem ele sempre se dirige, deve proceder, de acordo com os ensinamentos de Jesus, contidos no Novo Testamento, os quais lhe impõem buscar, em primeiro lugar, $O$ reino de Deus... o sumo bem... Procura-se pela fé, pela esperança e pela caridade. A justiça, porém, do reino consiste em observar tudo o que Cristo ensinou. Buscar o reino é transformar em obras a própria justiça a qual tem, pois, uma tríplice dimensão, dado que se alicerça no $1^{1}$ Mandamento: 'amar a Deus sobre todas as coisas e ao próximo como a si mesmo'. Por conseguinte, os católicos, cujo cuidado do negócio secular detém ocupados, [os quais] não abundam de tão grandes riquezas de virtudes, têm deveres morais para com a Trindade, para consigo mesmo e para com os semelhantes, deveres esses que os obrigam à inocência de vida... perfeição da caridade fratema... seis obras de misericórdia... duplo gemido da contrição... pelos pecados cometidos e omitidos".

Acima de tudo, em relação à Trindade, todo católico deve cultivar a virtude da fé porque primeiro [é preciso] acreditar [com] o coração, [para] depois ir trabalhar."

Ora, parece-nos, outrossim, imperioso e necessário começar a tratar deste assunto ressaltando em que consiste a virtude da Justiça, sob a ótica cristã, em sua tríplice dimensão, a fim de que se possa notar com clareza toda a sua amplitude, muito mais lata do que idéia, por sinal assás conhecida, que os gregos, romanos e outros povos tiveram acerca da mesma.

Santo Antônio, como vimos acima, sempre conceitua essa virtude e a explica, baseando-se, de um lado, na Auctoritas veto e neo-testamentária, e de outro, na acepção que os Padres da Igreja recolheram dos estóicos (Cícero, De Officiis). Encontramos tal denotação, por exemplo, numa passagem do sermão referente ao $4^{2}$ Domingo depois da Páscoa: A justiça é dar a cada um o que lhe pertence, de-

4 Procederemos dessa maneira, com vista a mostrar o pensamento do Santo em dois momentos distintos, uma vez que, de acordo com Pinto Rema, op. cit. Introdução: XXX, esses dois conjuntos foram escritos em ocasiōes diferentes. O primeiro deles, entre 1227/29, o segundo, incompleto, porque Antonio faleceu antes de o concluir, entre o outono/inverno de 1231.

$15^{\circ}$ Domingo depois de Pentecostes, vol. II: 127, cfr. também Mt VI, 24-33.

$2^{a}$ Domingo depois da Epifania, vol. II: 595-596.

21² Domingo depois de Pentecostes, vol. II: 299. 
pois de feito um juízo recto. Justiça é como que o estado de direito. Justiça é o hábito do ânimo de, guardado o bem comum, atribuir a cada um aquilo que merece.

As partes da justiça são: temer a Deus, venerar a religião, piedade, humanidade, o amor do equitativo e do bom, o ódio do mal, o empenho de prestar um favor." Igualmente encontramos a mesma conceituação, porém, apresentada de maneira mais sucinta, num trecho do sermão referente ao $6^{2}$ Domingo depois de Pentecostes, cujo passo evangélico lido na missa contém o seguinte versículo: 'Se a vossa justiça não exceder à dos escribas e dos fariseus, não entrareis no reino dos céus' (cfr. Mt V, 20). Diz o Santo: 'justiça é dar o seu a seu dono, depois de recto juizo', chama-se-lhe assim por ser como que o estado de direito"."

Deparamo-nos também, num trecho do sermão alusivo ao $20^{\circ}$ domingo depois de Pentecostes, com a idéia de aequitas, como que significando a essência do conceito de Justiça, uma vez que "a equidade" consiste em "dar a cada um o que lhe pertence".

Sob o aspecto filosófico, percebemos nessas definições que o Santo professava o jusnaturalismo, concepção essa que defende a idéia, segundo a qual a lei natural, radicada na lei eterna ou divina, de um lado, faz com que o ser humano ontológica e moralmente possua uma natureza comum, mediante a qual ele é capaz de identificar os primeiros princípios morais, e de outro, o faz igualmente sujeito de direitos e deveres, a tal ponto que a lei do seu Deus está no seu coração, porque no coração do justo está a lei do amor divino."

Por isso, o Doutor Evangélico num passo do sermão referente ao XXI domingo depois de Pentecostes, tratando da hierarquia angélica, e se baseando num versiculo de Ezequiel (cfr. X, 7), onde está escrito: 'Um querub estendeu a mão do meio dos querubins para o fogo, que estava entre os querubins; e o tomou e o colocou nas mãos daquele que estava vestido de roupas de linho', e no significado do termo Querubim, apresentado por Pedro Lombardo: 'Querubim interpreta-se plenitude de ciência. Esta é a caridade’ (cfr. Sentenças II, dist. 29, 5,: 439), identifica a virtude da Justiça com a da Caridade, pelo fato de a mesma, no seu entender, também possuir uma tríplice dimensão, a saber, o amor que devemos ter para com Deus, para conosco mesmo e para com o nosso semelhante, de modo que é preciso começar a ser caridoso consigo mesmo, para depois... ser caritativo para com os outros. ${ }^{12}$

Voltando, porém, aos dois primeiros textos antonianos antes citados, concernentes ao seu conceito de Justiça, na seqüência do primeiro, o Santo Ulissiponense, argumentando através da via do contrário, afirma que o mundano não é justo em relação à Trindade porque não teme a Deus, desonra a religião, odeia o bem, é ingrato para Deus. ${ }^{13}$

Vol. I: 405.

Vol. I: 682.Cfr. Agostinho, De Libero Arbitrio, I, 13, 27 PL 32: 1235.

Vol. II: 260.

$5^{9}$ Domingo depois de Pentecostes, vol. II: 453.

Vol. II: 289.

$4^{2}$ Domingo depois da Páscoa, vol. I: 405. 
Quais argumentos justificam, então, que o católico deva amar a Trindade e como ele efetiva isso? O católico deve amá-La, antes de mais nada, porque Deus o amou primeiro, pois 'nisto se manifestou a caridade de Deus para conosco, em que Deus enviou o seu Filho unigênito, para que por Ele tenhamos a vida' (cfr. 1Jo IV, 8-9), e porque Cristo 'tendo amado os seus que estavam no mundo, amou-os até ao fim' (cfr. Jo. XIII, 1), libertando-o das garras de Satanás, e assim, fez com que ele igualmente ressurgisse para uma nova vida, conforme ensina o Apóstolo, na Carta aos Romanos (cfr. VI, 3-4): 'Todos os que fomos batizados em Jesus Cristo, fomos batizados na sua morte... como Cristo ressuscitou dos mortos... assim nós vivamos uma vida nova...'. Noutras palavras, o católico se transformou, mediante o seu Batismo, nos méritos da Paixão e Morte do Senhor, num homo novus et renatus mediante a graça, fato esse que, em contrapartida, the impõe ver Deus e o mundo de outra maneira, diferente daquela que o homo naturalis da antiguidade via os seus deuses. Com efeito, é bem verdade que a pietas greco-romana impunha a esses povos a reverência para com os deuses, uma vez que os reconheciam como criaturas superiores que podiam interferir ao seu bel querer nos destinos e em todos os negócios e aspectos da vida dos homens. Por isso, também a religião deles tinha um culto, mas a dimensão do mesmo se restringia ao principio do ut des, quer dizer, reverenciavam suas divindades, fazendo-Ihes sacrifícios, ou propiciatórios ou em ação de graças, com o fito de respectivamente ou obterem apenas beneficios materiais ou agradecerem por aqueles que tinham recebido. Entretanto, podia ser que a divindade reverenciada não se sentisse agradada com aquele sacrifício, porque não se tinha observado o minucioso ritual e as fórmulas apropriadas, e então, ou os deixava de ajudar, e o que é bem pior, ou os castigava. Portanto, os gregos e romanos e outros povos da antiguidade desconheciam as idéias acerca de um Deus criador, redentor e santificador.

O católico, outrossim, deve amá-La e ser-Lhe grato, à semelhança daquele leproso que, tendo notado que Cristo o curara de sua doença, voltou atrás para agradecer-Lhe pelo favor recebido (cfr. Lc., XVII, 11 e seguintes), bem como porque Ela o sustenta nas suas fragilidades físicas e espirituais, cumulando-o com mercês nestes aspectos, fato esse que, segundo Santo Antônio, o obriga, então, a dar graças ao Senhor pelos benefícios recebidos, entoar cânticos de louvor e acção de graças a Deus, doador de todos os bens, ${ }^{1}$ e prestar atenção à misericórdia do Pai... para que tenha confiança, à excelência da Fé... para que despreze os bens temporais, à virtude do Baptismo, para que permaneça forte no combate. ${ }^{16}$

O Santo, fundamentado na passagem de Lucas (X,27), que narra o diálogo ocorrido entre Jesus e um certo doutor da lei que, à indagação do Senhor, lhe respondeu dizendo: "Amarás o Senhor teu Deus com todo o teu coração e com toda a tua alma e com todas as tuas forças e com todo o teu espíito", apresenta, outrossim, um argumento de razão teológica, haurido num preceito da Lei Escrita, que determina que o cristão proceda dessa maneira. Alega, igualmente, em favor de sua tese que ele deve reconhecer que o Pai, Criador, onisciente e onipotente, exerce um domínio sobre todas as criaturas, dado esse que, em contrapartida, the

$14^{a}$ Domingo depois de Pentecostes, vol. II: 94-95.

$17^{\circ}$ Domingo depois de Pentecostes, vol. II: 200. 
impõe se reconhecer criatura frágil e pecadora, de modo que, se recordando sempre da seqüência do mencionado diálogo entre Cristo e aquele Doutor da Lei: 'Faze isto e viverás', há de também ser humilde para com a Trindade, homenageando-A, porquanto, quem $\mathrm{A}$ ama acima de todas as coisas, desejando a verdadeira vida, despreza tudo o que possui neste mundo, ${ }^{16}$ pois a cobiça e o apego aos bens materiais e a outros atrativos e prazeres que o mundo oferece o impedem de mostrar honra e reverência, tudo o que somos, tudo o que podemos."

Ademais, dado que o católico sabe que a Trindade é o sumo bem, e o seu oposto é o mal, deve, outro tanto, não só abominar os vícios ou pecados, isto é, a concretização do mal, mas também evitar, ao máximo, cometê-los, bem como pedir-lhe perdão de seus pecados, antes, porém, arrependendo-se profunda e amargamente dos mesmos, pois as primícias do espírito são a contrição e a amargura pelos pecados... Tendo-as... não olham a trave no olho de outrem, não julgam ninguém, não condenam ninguém, antes gemem dentro de si mesmos na amargura da alma $^{18}$ e em seguida, ir confessar suas faltas a um padre [e] quando se confessa acusa todos os pecados e acolhe com humildade as repreensões do sacerdote ${ }^{19}$ pois quem... ao acusar-se justamente na confissão se julga a si mesmo, possui a morada do seu corpo em paz, na tranqüilidade de espirito," de modo que ao agir dessa maneira, ele está a assumir efetivamente que não $\mathrm{A}$ amou como tinha a obrigação de o fazer e por isso mesmo $\mathrm{A}$ ofendeu.

Por último, o católico, reconhecendo, com humildade, uma vez mais, sua condição de criatura contingente, deve implorar-Lhe tudo de que necessita, especialmente os dons espirituais, pois, de fato, qualquer cristão, filho da graça, deve pedir... a Deus Pai, para que o ame acima de tudo e a fé em Deus, a qual invisivelmente se gera no coração, se consagra pela graça invisivel do Espírito através da água do Baptismo, se alimenta com o auxílio invisivel da divina protecção, para não desfalecer, obra o bem de que é capaz com a mira nas coisas invisiveis."

A forma prática, no entanto, mediante a qual o católico demonstra o seu amor para com a Trindade é a oração. Fundamentado em Paulo, dirigindo-se a Timóteo (1Tm II, 1): 'Recomendo-te, antes de tudo que se façam súplicas, orações, petições, ações de graça', o Santo Franciscano diz primeiramente que o Apóstolo mostra a ordem a observar na oração e na súplica, e em seguida define e explica, com a clareza que the é peculiar, em que consistem esses gestos, ressaltando que absolutamente não é estranho pedir a Deus a concessão de bens materiais: a súplica consiste em ansiosa instância a Deus... A oração é afetuosa aderência do homem a Deus, entretenimento familiar e piedoso, estado da alma iluminada para gozar enquanto lhe é permitido.

\footnotetext{
${ }^{16} 13^{9}$ Depois de Pentecostes, vol. II: 32.

$176^{\circ}$ Domingo depois de Pentecostes, vol. I: 683, 684, 682.

$174^{g}$ Domingo depois de Pentecostes, vol. I: 632. Cfr. também Domingo de Páscoa, vol. I: 274-286.

$198^{a}$ sermão festivo Purificaçäo da Virgem Maria, vol. II: 757.

* $13^{2}$ Domingo depois de Pentecostes, vol. II: 32 .

70 $16^{2}$ sermão festivo: Rogaçōes, vol. II 909-910.

21 $16^{\circ}$ sermão festivo: Rogaçöes, vol. II 909-910.
} 
Petição é o empenho de obter bens temporais e o que é necessário à vida presente. Deus, se aprova a boa vontade do que pede, faz, todavia, o que ele mesmo julga melhor; em todo caso dá largamente àquele que pede bem...

É normal que todos os homens, mas sobretudo os filhos deste século, desejem a tranquilidade da paz, a saúde do corpo, a clemência do clima e outras coisas que respeitam ao uso e necessidade desta vida, mas que também são fontes de abuso e de prazeres maus. Aqueles que de coração puro pedem estes beneficios temporais, só os peçam na medida em que são necessários. $E$ também nisto mesmo sujeitem sempre a sua vontade à vontade de Deus..."

Numa passagem do sermão alusivo ao domingo seguinte, o Santo explica quais são as modalidades da oração, dizendo que ela é tripla: mental, vocal e manual. Acerca da primeira diz o Eclesiástico (cfr. XXXV, 21): 'a oração do que se humilha penetra os céus'. Sobre a segunda lê-se no Salmo: (cfr. 87, 1) 'Entre a minha oração na tua presença'. Sobre a terceira traz o Apóstolo (cfr. 1Ts V, 17): 'Orai sem cessar'."

Subentende-se, no tocante ao segundo tipo de oração, que esta há que ser feita através de palavras e fórmulas apropriadas, de acordo, v.g., com o ritual litúrgico da Igreja, relativo a todas celebrações sacramentais, à Liturgia das Horas, bem como suas prescrições respeitantes a outras práticas, as quais, outrossim, impõem ao católico que guarde os domingos e dias santificados, especialmente destinados ao louvor da Trindade, ou à memória da Virgem e dos Santos; comporte-se piedosa, reverente e adequadamente no templo, não conversando com os vizinhos, não olhando para os lados, não ficando desatento e participando ativamente de todas as celebrações.

As Rogações, por exemplo, três dias em que ao alvorecer se reza a Ladainha de Todos os Santos, diz o Santo são destinadas a rogar ao Senhor e a impetrar-lhe beneficios. Foram especialmente instituídas para rogar a Deus o perdão dos pecados,... e para impetrar benefícios de misericórdia, tanto em bens temporais, como em espirituais... ${ }^{24}$

Enfim, consoante o pensamento do Doutor Evangélico, uma outra forma de o católico manifestar o seu amor para com a Trindade, praticando-o, de fato, consiste em contemplar, meditar ou refletir sobre os principais fatos relativos à vida de Cristo, diretamente relacionados com o Mistério da Salvação, a saber, de que modo o Filho de Deus inclinou a cabeça da Divindade no ventre da Virgem pobrezinha... de quanta misericórdia e benignidade se manifestou para com os pecadores, que atraía a si com a doçura da sua pregação e comia com eles para os chamar à penitência; de quanta compaixão foi, ao chorar... sobre Lázaro... de quanta mansidão foi, quando quis falar sozinho com a Samaritana e permitiu ser tocado pela pecadora Madalena... de que modo foi ferido com varas e bofetadas, escarrado, coroado de espinhos, saciado de fel e vinagre, e crucificado entre ladröes (como se fosse um deles)... inquirir com subtileza de espírito de que modo a trom-

$225^{2}$ Domingo depois da Páscoa, vol. I: 444-445.

$6^{\varphi}$ Domingo depois de Pentecostes, vol. I: 476 . Cfr. também $3^{a}$ Domingo do Advento, vol. II: 479 .

21 $16^{\circledR}$ sermäo festivo, Rogaçōes, Vol.II: 915. 
beta toca, e os mortos, 'que dormem no pó da terra', na frase de Daniel (cfr. Dn XII, 2), 'acordarão uns para a vida etema, e outros para o opróbrio'. '

Santo Antônio reitera seu pensamento no que respeita a essa prática religiosa, num trecho do sermão moral $(\mathrm{V})$ integrante dos textos relativos à festa dos Apóstolos Pedro e Paulo. Haurindo-se nos versículos bíblicos: 'Alegra-te Zabulão na tua saida...' e 'Bem-aventurado o homem que encontrou a sabedoria e que é rico de prudência', (cfr. Prov. III, 13-14), primeiramente declara: Nisto verifica-se a doçura da contemplação, que nasce do amor [para com] o Criador. É mais precioso do que todas as riquezas, e não se lhe pode comparar qualquer coisa que se deseje. Em seguida, explicando o significado a palavra 'saída', constante daquele $1^{\mathrm{q}}$ versículo, acrescenta: Representa esta a vida contemplativa. Aquele que quiser aproveitá-la, não só tem de sair do mundo, mas também afastar de si as preocupações [com ele]... o amor [a] Deus chama o... homem interior ao monte, à excelência da contemplação santa quando o espírito se eleva na contemplação, então o povo reúne-se no monte, acabando a imaginação com o vão devaneio, os afectos com a ilícita concupiscência... ${ }^{*}$

Retornando, uma vez mais, aos textos antonianos, citados páginas atrás, referentes ao conceito de Justiça, num deles, considerado como sinônimo ou equivalente à virtude da Caridade, encontramos a $2^{\mathrm{a}}$ dimensão dessa virtude, a qual respeita ao amor que devemos ter para consigo próprio, fato esse que impõe ao católico praticar e cultivar uma série de virtudes para que bem prossiga em sua caminhada rumo à Pátria.

Entre elas, se enumeram alguns dos dons ou graças do Espírito: o conselho, para que fuja do mundo; a equidade, para dar a cada um o que lhe pertence; a prudência para se precaver contra os perigos; a fortaleza para que se mantenha constante na adversidade ${ }^{x /}$ De fato, o católico estando atento às exortações e aos conselhos de Cristo, despreza o mundo e seus atrativos, a fim de não se deixar cair nas armadilhas e seduções que ele prepara aos incautos; observa, à risca a equidade, porquanto não faz aos outros o que não gostaria de que fizessem consigo mesmo; é prudente e circunspecto ao se precaver contra as insídias do Maligno, ${ }^{2 B}$ e daqueles que, a seu serviço, propagam o mal no mundo; é forte, resistindo às seduções que estão à sua volta, e, ainda, exercitando a firmeza de sua vontade perante as tribulações e adversidades que 0 afligem.

O Espírito Santo, outrossim, ilumina o entendimento [de] todo católico para que sempre cultive: a fé no Verbo Encarnado, o amor [ao] próximo, a doutrina do Verbo divino, a luz do bom exemplo, a recta intenção do ânimo, a constância do propósito [final] ${ }^{m}$.

25 $8^{9}$ Domingo depois de Pentecostes, vol. I: 744-745.

*i $20^{2}$ sermão festivo Apóstolos Pedro e Paulo, Vol. II: 982, 983, 984-985. Cfr. também $13^{2}$ sermão festivo Páscoa da Ressurreição, vol. II: 858-859: A alma.:. quando é sacudida de si mesma... pela devoção do espirito... engorda com a doçura da contemplação... sobe do deserto em contemplaçāo, quando abandona todas as coisas inferiores, e ultrapassando até chegar ao céu, pela devoção toda mergulha só em coisas divinas.

Cfr. também $2^{2}$ sermão festivo Santo Estêvão Protomártir, vol. II: 651.

จ $2^{2}$ sermão festivo Santo Estêvão Protomártir, vol. II: 649. 
A par dessas virtudes/dons/graças, o católico no tocante a si mesmo, deve, ainda, cultivar outras mais, por exemplo, a mansidão, pois o manso, que não insulta nem se impressiona com insultos, que não escandaliza nem se escandaliza, merecerá ouvir... 'Hoje estarás comigo no Paraíso' (cfr. Lc XXIII, 43). O Paraíso é a terra dos vivos, possuída pelo [manso]. Os avarentos não possuirão esta terra, os quais... dilaceram o espinito a amontoar fortuna, escandalizam os outros a roubar. Por isso no dia do Juizo, ouvirão de Cristo: 'Ide, malditos, para o fogo eterno' (cfr. Mt. XXV, 41). . $^{\text {. }}$

O católico, outrossim, tem de cultivar a autodisciplina através dos sacrifícios corporais e de outros hábitos sadios, para que a alma dirija o corpo, e não o contrário, de acordo com o lugar preeminente que ela ocupa no ser humano, dada a sua natureza espiritual, a saber: a mortificação da vontade própria, a abstinência de comida e bebida, a censura do silêncio, as vigilias nocturnas em oração, o derramamento de lágrimas, a discreta ocupação da leitura, o exercício corporal, a compaixão pela necessidade alheia, a vileza do vestido, o desprezo de si mesmo... ${ }^{31}$

Para além de tais gestos, ele também há de cultivar a modéstia, a qual consiste sobretudo na paz do espírito e na honestidade do corpo. Sobre isto escreve Isaias (XXXII, 17): 'A paz será a obra da justiça, e o culto da justiça será o silêncio e a segurança sempiterna'. De fato, todo católico deve fundamentar a boa obra na paz do espirito. ${ }^{32}$

Tudo que o católico fizer, deverá ter reta intenção, quer dizer, Se a intenção for simples, sem a... fraude, toda obra será clara, porque iluminada com a lâmpada da recta intenção. ${ }^{3 .}$

Ele há de cultivar também a discrição, a qual é a ciência do bem e do mal. Esta é a verdadeira ciência. Só ela causa o saber, só ela faz sábios, ... é o exame ou consideração de qualquer coisa ... Portanto ... a árvore da vida honesta produz 0 fruto da edificação no próximo. A árvore da consciência pura produz o fruto da contemplação em Deus. A árvore da [discrição] produz o fruto da bondade em ti mesmo. $^{\text {x }}$

Enfim, deve o católico praticar a honestidade da vida, a doçura da contemplação e a extinção da sensualidade... A primeira decorre da consciência tranquila, a qual se possui mediante a condigna satisfação dos males passados, através do Sacramento da Penitência, e por intermédio do cauteloso e providente afastamento dos males presentes. Com efeito, a vida honesta é formosa e suave, porque nada há de torpe na acção, disforme na palavra, indecente no gesto ou no movimento. Desta maneira, basta a cor da sua formosura... para alimentara vista do próximo..." A segunda e a terceira obtém-se ao ser desprendido dos bens materiais e dos atrativos que o mundo oferece, porque a alma... se suspende... [e] perde a esperança no deleite do corpo e no tempo presente. Não cuida de forma alguma em

\footnotetext{
$23^{2}$ Domingo depois de Pentecostes, vol. II: 372-373.

Domingo de Pentecostes, vol. I: 496.

$3^{2}$ Domingo do Advento, vol. II: 474-475.

$2^{2}$ sermão festivo Santo Estêvão Protomártir, vol. II: 651.

$15^{2}$ sermão festivo Invenção da Sta. Cruz, vol. II: 898.

$15^{2}$ sermão festivo Invenção da Sta. Cruz, vol. II: 897-898.
} 
viver mais, como costumava, porque 'já não é ele que vive, mas vive nele a vida de Cristo' (cfr. Gl II, 20). ${ }^{26}$

No nosso entender, porém, o elenco mais global das virtudes que o católico há de praticar simultaneamente em relação a Deus, a si próprio e aos outros se encontra numa passagem dum sermão moral, integrante dos textos referentes à festa dos apóstolos Pedro e Paulo. Com efeito, o Santo, baseando-se num trecho do Livro dos Números (XXIV, 5-6), onde está escrito: 'Quão formosos são os teus pavilhões, ó Jacó, e as tuas tendas, ó Israel! São como vales selvosos, como jardins junto dos rios que os regam, como tendas que o Senhor plantou como cedros juntos das águas', diz o seguinte: Jacob... figura o varão activo... 'Os pavilhões ou tendas' são a milícia de sua vida santa, que são e devem ser formosos, pela honestidade de costumes; 'como vales selvosos', pela humildade do espínto, que dão sombra contra o incentivo da came; 'como jardins irrigados junto dos rios', pela abundância das lágrimas; 'como tendas que o Senhor plantou', pela constância de ânimo e pela perseverança final; 'como cedros', pela altura da esperança, pelo odor da boa fama, que afugenta as serpentes da detracção; 'junto das águas', isto é, junto dos carismas das águas..."

Retornando novamente aos textos antonianos, citados páginas atrás, referente ao conceito de Justiça, seja aquele em que ele se fundamenta na definição ciceroniana, ou aquele outro em que o Santo a considera como sinônimo ou equivalente à virtude da Caridade, encontramos a sua $3^{\mathrm{a}}$ dimensão ética, a qual respeita ao amor que devemos ter para com o próximo. Como, então, no entender do Doutor Evangélico, o católico efetiva tal dimensão da Justiça ou pratica o mandamento da caridade fraterna?

Antes, porém, de responder a essa pergunta, não nos parece despropositado recordar que o homo naturalis, grego ou romano, e os Estados em que estavam inseridos, seja por força da filantropia ou da pietas, ensinadas pelos filósofos, ou da religião que praticavam, seja por motivos de ordem político-social, como a estabilidade e a paz internas, tiveram e cultivaram o sentimento de compaixão pelo semelhante, face principalmente às várias espécies de desgraças e de misérias que o acometem, entre as quais as de natureza material, por exemplo, a indigência, a deficiência fisica, a carência de abrigo, os cataclismos, as fomes, as misérias, os estios prolongados, as epidemias, os invernos gélidos e torrenciais, etc, etc.

Ora, como sabemos, desde os seus primórdios, o Cristianismo, por onde se irradiou, alicerçado no Novo Mandamento, provocou uma verdadeira revolução no que tange às relações sociais e morais, especialmente para com os carentes. De fato, sabemos, outrossim, que foi desde então que surgiram, por exemplo, os asilos, os hospitais, os orfanatos e pessoas que se dispuseram, por amor a Deus e ao próximo, ou a trabalhar nesses locais, ou a ajudá-los financeiramente para que fossem mantidos. O Novo Mandamento, portanto, impõe a todo católico ajudar espiritual e materialmente o seu próximo. É bem verdade, porém, que mais tarde, esse dever acabou ficando como algo da responsabilidade exclusiva da Igreja e de seus ministros, homens ou mulheres, e talvez, nos dias de hoje, não seja um exa-

36 $13^{2}$ sermão festivo Páscoa da Ressurreição, vol. II: 856, 857, 859-860.

37 Vol. II: 984. 
gero afirmar que a maior parte das pessoas ainda pense que assim é e tem de ser, isto é, que cabe às várias igrejas e às instituições filantrópicas fazer caridade para com os despossuidos. Essa maneira de pensar e de ver a dura realidade social a nossa volta, no entanto, não só é muito comodista, mas também carregada de um individualismo egoísta, regido pela lei do amor a si mesmo. Na verdade, se o homem amasse o seu semelhante como ama a si mesmo, com certeza não haveria tanta injustiça e conflitos sociais, tanta comupção política ativa e passiva, tanto jogo de interesses escusos, porque espontaneamente ele se moveria em socorro do outro, em toda necessidade que se lhe apresentasse.

Santo Antônio julgava, pois, com muita propriedade que aquele mandamento/dever era e é da alçada de todos os cristãos leigos, ou particularmente consagrados ao serviço de Cristo e do próximo. Muitos são, pois, os trechos de seus sermões Dominicales ou Festivi em que ele tratou minuciosamente deste aspecto, do tema em apreço. A propósito diz ele: $\dot{E}$ da vontade de Deus o amor a si mesmo e ao próximo, a qual foi escrita na lei da natureza, da letra e da graça, e confirmada perante testemunhas, aos quais disse: 'Este é o meu mandamento, que vos ameis uns aos outros' (Jo. XIII,1. Este testamento foi confirmado na morte do testador. Esta frase do Santo é de uma clareza meridiana. Segundo ele, a natureza, a lei mosaica e a lei evangélica são totalmente coincidentes ao prescrever a todos os homens, como norma de conduta universal, que amem o seu semelhante. De fato, pela divida do amor estou ligado a todo o homem. Sinto-me obrigado sempre a cumpri-lo. Se o cumpro como devo... não devo a ninguém qualquer coisa além disto. Todo aquele que me pede outra coisa que não seja esta, já não anda segundo $o$ amor. ${ }^{\text {* }}$

A par disso, consideremos, outrossim, aquele outro conceito de Justiça: dar a cada um o que lhe pertence, depois de feito um juízo recto. A ação de dar a cada um o que é seu supõe sempre duas ou mais pessoas, físicas ou jurídicas, fato esse que transforma a Justiça numa virtude social, pois o ser humano para sobreviver e se realizar necessita das várias comunidades em que se insere e de Instituições das quais participa, entre as quais a mais importante de todas é o Estado, para cujo bem comum, cada pessoa está obrigada a dar a sua parcela. Por outro lado, essa definição também ressalta que a Justiça se refere concretamente a cada um e a todos os indivíduos, o que implica, outro tanto, na existência de regras normatizadoras das relações sociais, cujas leis (positivas) são a exteriorização. Enfim, a expressão final daquele conceito pressupõe também, da parte das pessoas, uma operação intelectual, mediante a qual elas são racionalmente capazes de distinguir o falso do verdadeiro, o justo do injusto, o certo do errado, o bem do mal, ainda que, depois, ao agir, não venham a proceder corretamente, porque, como diz o Santo, "não querem guardar nem a lei da letra, como servos, nem a lei da graça, como filhos" de modo que "mudam o direito natural, que é "não faças aos outros o que não queres que te façam a ti'..."

XIII Domingo depois de Pentecostes, vol. II: 29.

$393^{2}$ depois da oitava da Epifania, vol. II: 612.

* Domingo da Septuagésima, vol. I: 12. 
Ora, nesta perspectiva, a maneira mais perfeita de a Justiça se efetivar, contemplando plenamente a sua dimensão ético-social, é sem dúvida alguma através da prática da virtude da Caridade, seja no âmbito espiritual quanto no material, cujo conjunto de atitudes ou gestos costuma-se denominar de obras de misericórdia. Vamos, pois, examinar os ensinamentos do Doutor Evangélico no tocante aos dois âmbitos em separado, com vista a caracterizar precisamente o que é esta virtude cristã; a mostrar como não só ela se distingue da filantropia ou da pietas greco-romana, que o homo naturalis virtuoso costumava praticar, mas também a ressaltar a idéia de sua obrigatoriedade da parte de todo católico.

Comecemos, pois, tratando das obras de misericórdia espirituais, isto é, aquelas precípua e diretamente relacionadas com a alma.

Numa passagem de um sermão integrante dos textos alusivos ao $4^{0}$ Domingo depois de Pentecostes, Santo Antônio fundamentando-se num trecho do EvangeIho de Lucas (VI, 36-38), onde está escrito: 'Sede misericordiosos, como também vosso Pai celeste é misericordioso. Não julgueis e não sereis julgados; não condeneis e não sereis condenados. Perdoai e sereis perdoados. Dai e dar-se-vos-á', bem como num trecho da Carta de Tiago (V, 5), em que o Apóstolo diz: 'Quem converter um pecador do erro da sua vida, salvou a alma dele e cobre uma multidão de pecados', e igualmente na definição de misericordioso apresentada por Isidoro de Sevilha, segundo o qual 'misericordioso é aquele que tem compaixão da miséria alheia' (Etymologias X, 165 PL 82: 384), exorta e afirma que todo católico tem de perdoar a quem 0 ofendeu, tanto de coração quanto verbalmente; de aconselhar 0 próximo que se afastou do caminho do bem, para que retorne ao mesmo, trazendo-o do vício para a virtude, não só mediante palavras, mas sobretudo por meio dos bons exemplos, e deve, ainda, corrigir o semelhante que erra ou que está a pecar, ou por causa de sua tibieza ou preguiça. Eis suas palavras: ofereçamo-nos de guia aos que desconhecem o caminho; castiguemos com a voz da pregação os preguiçosos e os tíbios... transportemos... os enfermos e os débeis, para que não desfaleçam no caminho; vigiemos... com a oração... e a contemplação; agarremos a pobreza do Senhor, a sua humildade e a amargura de sua paixão."

Dai, o Santo, numa passagem dum outro sermão, fundamentando-se novamente em Isidoro de Sevilha, comparar muito apropriadamente a figueira, a qual é mais fértil do que as outras árvores. Dá fruto duas ou três vezes por ano. Começando a amadurecer um, nasce outro' (cfr. Etym. XVII, 7, 17 PL 82: 612), com a caridade fratema, a mais fecunda de todas as virtudes, porque corrige o que erra, perdoa ao que peca contra si, dá de comer ao faminto; quando pratica alguma obra de misericórdia, pensa logo noutra que amadureça, produza boa obra."2

Numa passagem dum outro sermão, o Santo Menorita destaca, ainda mais claramente, como se há de ser misericordioso para com o semelhante: se o teu próximo é cego pela soberba, quanto está em ti ilumina os seus olhos com o exemplo da humildade; se é coxo pela hipocrisia, põe-no direito por meio de obras de verdade; se é leproso pela luxúria, limpa-o com a palavra e o exemplo da casti-

${ }^{41}$ Vol.I : 609. Cfr. também 20 Domingo depois de Pentecostes, vol. II: 250.

${ }^{42} 15^{2}$ sermão festivo, Invenção da Sta. Cruz, vol. II: 897. Cfr. outrossim, 20 Domingo depois de Pentecostes, Vol. II: 250, 251. 
dade; se é surdo pela avareza, propõe-lhe o exemplo da pobreza do Senhor; se [está] morto pela gula e embriaguez, ressúscita-o com o exemplo e virtude da abstinência; aos pobres, porém, anuncia a vida de Cristo. ${ }^{3}$

Todavia, a fim de que os católicos efetivamente saibam perdoar o próximo, corrigi-lo, quando for necessário, e sempre dar-lhe bons exemplos e conselhos, tal qual sua condição de batizado lhe impõe, é preciso também que roguemos ao Senhor Jesus... pai misericordioso, nos infunda a sua misericórdia, para que tenhamos misericórdia para conosco e para com os outros, não julguemos nem condenemos ninguém, perdoemos ao que peca contra nós e demos a todo o que pede o que somos e o que temos."

Na verdade, ressalta o Doutor Evangélico, quem é misericordioso para com os outros, Deus será misericordioso para com ele. Os judeus, sem misericórdia,... ofereceram... um copo [com] ... vinagre misturado com fel... Cristo provou a amargura. Isto mesmo fazem hoje a Jesus Cristo os falsos cristãos, piores que os judeus, e por isso não acharão misericórdia no tempo da tribulação."

O católico efetiva igualmente a virtude da Caridade/Justiça para com o semelhante, sob o aspecto material, de várias maneiras, em especial, através da esmola. A propósito, diz Santo Antônio: Grande tesouro é a esmola... Entesoura no céu aquele que dá a Cristo; dá a Cristo o que distribui ao pobre. 'O que fizestes', diz, a um dos meus mais pequeninos, a mim o fizestes' (cfr. Mt XXV, 40). Por isso, o céu seja para ti o pobre; põe nele o teu tesouro, a fim de que o teu coração esteja ali sempre e sobretudo nesta santa Quaresma. ${ }^{\text {. }}$

De fato, o católico, através da esmola direta ou indiretamente oferecida ao necessitado, vive igualmente algumas dentre as obras de misericórdia, pois, ou está a dar-lhe de comer, ou a matar a sua sede, ou a vesti-lo, ou até mesmo a hospedá-lo.

Mas para além da esmola, sob o aspecto material, o católico pratica a Caridade/Justiça em relação ao próximo, estando sempre pronto e disposto a fazer-lhe o bem, com reta intenção e pureza de coração, em especial quando é solidário e tem misericórdia, para com todos os marginalizados, entre os quais os anciãos, os pobres, os enfermos, os aflitos, os prisioneiros, os nascituros, as crianças e adolescentes abandonados que estão à sua volta; em relação à sociedade como um todo, ao denunciar e a combater o mal, através das palavras, escrita ou falada, e igualmente por meio de bons exemplos, por mais insignificantes que sejam. De fato, afirma o Doutor Evangélico: A mão... representa o trabalho, que devemos estender à utilidade do próximo... Usa duas [partes da mão] quando ministra ao próximo o alimento da alma e do corpo... Nesta mão, portanto, devemos ter as ofertas da virtude, da caridade e da esmola, o incenso da devoção interior, de modo que façamos com devoção tudo quanto fazemos... aquele que procura louvores [por causal das suas boas obras nem 'apresenta ofertas na casa do Senhor' nem o 'fumo do' seu 'incenso sobe à presença de Deus' (Ap VIII, 4). Isto ensina-nos a

\footnotetext{
$232^{g}$ Domingo do Advento, Vol.II: 458.

n Ibidem: 615 .

$43^{2}$ Domingo depois de Pentecostes, Vol. II: 375.

4. $10^{2}$ sermão festivo, Quarta Feira de Cinza, vol. II: 803.
} 
oferecer na... consciência pura, onde ele habita, diante dele, a oblação da nossa obra, e a esperarmos somente dele a recompensa. $E$ assim, por ministério do nosso Anjo da guarda, a nossa oração subirá à presença de Deus, e a sua graça descerá até nós, a fim de à sua glória finalmente podermos subir."

É, aliás, por essas razões que a Igreja celebra as festas em louvor da Virgem Maria e dos Santos, pois, dado que praticaram a virtude da Caridade/Justiça, servem de exemplo e de modelo a todo católico, o qual deve, outrossim, rogar-lhes que lhe conceda a graça de os imitar. Tal é o que ocorreu com S. João. Com efeito, por ter temido a Deus com temor filial e casto, praticou boas obras, dedicou-se [à] obras de caridade. Além disso, nas suas três Epístolas falou sobre o que é a verdadeira caridade cristã de modo só possível a alguém que a possuísse."

Os egoístas mundanos, ao contrário, no que respeita à sociedade, esquecendo-se do bem comum, não se importam com os problemas sociais que estão ao seu redor, fazendo vista grossa para com os mesmos. Por isso, mais do que ninguem, os dirigentes políticos cristãos, governantes, juizes, legisladores e demais autoridades, diferentemente deles, tendo sempre em mente o bem comum, por exemplo, não só devem fazer com que a Justiça seja célere, mas ainda têm de tomar as providências necessárias para que os criminosos, sem exceção e ou privilégio, venham a ser punidos com castigos que se revertam em proveito de toda a sociedade, v.g., mediante um número infinito de ocupações, atividades e trabalhos compulsórios e remunerados, uma vez que esta foi agravada na pessoa de um de seus membros, que não pôde ou não pode lhe retribuir com a "pena de Talião". Semelhantemente, por outro lado, o Estado tem de proporcionar segurança às pessoas, para que possam viver tranqüilas e não venham a se desesperar e se revoltar, querendo fazer justiça "com as próprias mãos", e a " torto e a direito", ao ponto de andarem armados, ou criarem e manterem, por auto-iniciativa, grupos de justiceiros ou de milícias armadas, provocando uma instabilidade social, ainda muito maior.

Outrossim, há um grave desrespeito ao bem comum e uma flagrante injustiça social, quando, por exemplo, o Estado e seus dirigentes anuem que um número considerável de pessoas concentre em suas mãos um enorme patrimônio fundiánio que absolutamente não se destina nem para o cultivo de flores.

$\mathrm{Na}$ verdade, o amor [ao] próximo chama ao monte, às alturas da dilecção fraterna... o homem exterior, a fim de que os membros e os sentidos sirvam o próximo e the ministrem o necessário... Sobe o monte aquele que ama o próximo... o suporta... lhe administra o necessário."

4 $16^{2}$ sermão festivo, Rogações, vol. II: 918. Cfr. também $20^{2}$ sermão festivo, Apóstolos Pedro e Paulo, Vol. II, 982-983: "Issacar... é o amor [ao] próximo. Baixa o ombro para levar os seus fardos, segundo... o Apóstolo aos Gálatas: 'Levai os fardos uns dos outros e assim cumprireis a lei de Cristo'. (cfr. VI, 2) $O$ amor laol próximo chama-se asno forte, porque transporta as suas cargas neste mundo, para receber a recompensa na pátria. Daí o salmista dizer: 'Quando tiver dado o sono aos seus dilectos, eis, ó filhos, a herança do Senhor; o fruto do ventre é uma recompensa'... Quando, portanto, depois do trabalho, tiver dado o sono descanso... àqueles que foram ligados com os vínculos do duplo amor... (este descansol é a recompensa do filho, adoptado por meio da graça, fruto do ventre, fruto da Mãe Igreja..."

48 sermão festivo, S. João Evarigelista, vol. II: 663.

$20^{\circ}$ sermão festivo, Apóstolos Pedro e Paulo, vol. II: 985. 
Por isso, julgamos que os politicos cristãos têm o dever, por exemplo, de fazer com que o Estado reparta essas terras com. um número muitíssimo maior de famílias, a fim de que não apenas elas possam vir a obter o seu próprio sustento mediante os trabalhos agropastoris, mas também contribuam para que, através da agricultura ou da pecuária leiteira ou de corte, outras pessioas mais se beneficiem por intermédio dessas atividades laborais, as quais, certamente, redundarão em proveito de toda a sociedade.

Enfim, os cristãos autênticos, tendo vivido durante a sua caminhada neste mundo rumo à Pátria, as virtudes da Caridade/Justiça, após o seu transitus, e depois de o juiz supremo ter examinado perfeitamente as palavras, os actos e toda nossa vida... [nos fará] imortais e bem-aventurados... para que... cantemos, dando graças eternamente... "

60 $6^{a}$ Domingo depois de Pentecostes, vol. I: 682. 